\title{
SPIRITUALITATEA SFÂNTULUI SILUAN ATHONITUL
}

Dan VÎRBAN*

\begin{abstract}
The spirituality of Saint Silouan Athonite (Semion Ivanovici Antonov) ${ }^{l}$. Taking a look at the Orthodox spirituality of the twentieth century, we can easily notice one of the greatest spiritual pillars that have lived in Holy Mount Athos, Saint Silouan Athonite. In 1896 he became a monk on Mount Athos from where he also left this life in 1938. At first glance, his life seems a trivial one, no different from that of an almost illiterate Russian peasant. Reading these things, we wonder what was so remarkable in this man's life. I believe that the greatest events and accomplishments take place in the heart of man, and that is why Saint Silouan can be called one of the most representative icons of Orthodox spirituality, because since the beginning of his monastic life, he was worthy of God's sight. In a moment of deep despair, the Savior appeared to the young man, giving him the following guidance: "Keep your mind in hell and despair not." The present study analyses therefore the main aspects of Saint Silouan Athonite spirituality and influence on which this had on the thought of his disciple Father Sofronie Sakharov. Practically the whole experience of Saint Silouan will be characterized by this dictum divine. The fulfillment of this divine commandment brings the human being into a kenotic state in which by grace, overcomes even the most subtle attacks of pride. Keeping the mind in hell prepares man for the sight of God, which is equivalent to the birth of man as hypostasis or to the acquisition of resemblance. In the state of hypostatic living in the human being as a person, prayer is made for all Adam and for all creation. This prayer is similar to that raised by the Savior in the Garden of Gethsemane. The spirituality of the peasant Semion Ivanovich Antonov will be known
\end{abstract}

“Priest, PhD Student, Faculty of Orthodox Teology at „1 Decembrie 1918” University, Alba Iulia, Romania.

${ }^{1}$ Studiu redactat sub îndrumarea Pr. Prof. Univ. Dr. George Remete, care şi-a exprimat acordul pentru publicare. 
to the whole world through his disciple, Archimandrite Sophrony Sakharov. In fact, the entire theology of Father Sofronie will have its starting point in the person of Saint Silouan Athonite.

Keywords: Saint Silouan Athonite, Father Sofronie Saharov, the whole Adam, the sight of God, the prayer of Gethsemane.

\section{Introducere}

Cunoscut lumii ca Sfântul Siluan, Semion Ivanovici Antonov, a lăsat una din cele mai reprezentative icoane de trăire duhovnicească ale secolului XX. Scopul acestui articol este de a evidenția principalele aspecte ale teologiei sale. Potrivit biografului său, părintele Sofronie Saharov, Semion Ivanovici Antonov s-a născut în anul 1866 în satul Şovsk, districtul Lebedinsk, din gubernia Tambov ${ }^{2}$.

Își face întâi stagiul militar, iar apoi în 1892 alături de ajutorul rugăciunilor Sf. Ioan de Kronștadt ajunge în Sf. Munte (voi reveni în cele ce urmează perioada vieții sale din muntele Athos, perioadă ce reprezintă de fapt timpul marilor descoperiri duhovnicești). În 1896 tânărul Semion ajunge monah, iar în 1911 schimonah. Printre ascultările avute putem menționa: la moară, la Kalamareia, la Vechiul Russikon, la economat ${ }^{3}$. În data de 24 septembrie 1938, între ora 1 și 2 noaptea, starețul a trecut la cele veșnice ${ }^{4}$.

După cum afirma părintele Sofronie, la prima vedere, viața sa pare una destul de banală, nefiind cu nimic deosebită de cea a unui simplu monah. De altfel chiar și în timpul vieții el nu a fost considerat drept un părinte harismatic nici chiar de monahi. Dar adevărata viaţă a omului se petrece în planul interior în duh și mai puțin în planul exterior.

\section{1. Ține-ți mintea în iad și nu deznădăjdui}

În timpul vecerniei, în paraclisul Sfântului Ilie de la moară, în dreptul icoanei Mântuitorului, Sfântul Siluan se învrednicește sa-L vadă pe Hristos.

2 Viața și învățătura starețului Siluan Athonitul scrise de ucenicul său arhimandritul Sofronie, Sibiu, Edit. Deisis, 2004, p. 7.

${ }^{3}$ Ibidem.

${ }^{4}$ Ibidem, p. 275. 
Întotdeauna vederea lui Dumnezeu este precedată de mari suferințe, de chinurile deșertării de sine: „Vederea lui Dumnezeu e precedată de mari suferințe de belșug de lacrimi, de lacrimi fierbinți țâșnind din inimă și care mistuie în om trufia trupească, sufletească și duhovnicească"s.

Această vedenie îi prilejuiește o mare bucurie. Când sufletul omului este cercetat de har atunci el uită toate cele ale lumii, le uită toate frumusețile pământești toată ființa sa fiind cucerita de frumusețea și dragostea lui Dumnezeu.

Timp de 15 ani, el nu-și micşorează deloc nevoințele. Mai mult, asalturilor demonilor se întețesc. Părintele Sofronie Saharov, biograful vieții sale, notează un amănunt foarte important. În momentul în care se ruga, un diavol s-a interpus între Sf. Siluan și icoană. Atunci marele nevoitor strigă deznădăjduit către Dumnezeu. În acea clipă el primește în inima sa următorul răspuns: „T, Tine-ți mintea în iad și nu deznădăjdui”. Acum tainele Împărăției Cerurilor i se descoperă unui om simplu și neînvățat: „În noaptea acelei rugăciuni-convorbiri, tainele ascunse de cei în̦̦elepți și cei pricepuți au fost dezvăluite și starețului Siluan, om simplu și neînvățat. Această noapte are o însemnătate excepțională în viața sa"6.

Putem spune că întreaga spiritualitate a Sfântului Siluan este concentrată în cuvintele Ține-ți mintea în iad și nu deznădăjdui. Aceste cuvinte rostite de Mântuitorul în inima marelui ascet rus, reprezintă de fapt esența întregului parcurs spre îndumnezeire a ființei umane. Cuvântul dat de Domnul Iisus Hristos marelui sfânt rus îl ferește pe om de cele două mari prăpastii pe care le întâlnește în drumul său de la chip la asemănare. Prima prăpastie este ilustrată de gândul: Ești sfânt, iar a doua de gândul $\mathrm{Nu}$ te vei mântui. În prima parte a poruncii este împiedicată ispita fricii, iar sufletul începe să afle smerenia, iar în partea a doua reprezintă biruința asupra deznădejdii prin nădejdea mântuirii.

Prin acest gând Sfântul Siluan începe să învețe adevăratele dimensiuni ale smereniei. Această poruncă dumnzeiască o putem pune în strânsă legătură cu imaginea scării din opera Sf. Ioan Scărarul, Scara Raiului. În primul și primul rând cuvântul scară ne duce cu gândul la un urcuș. Urcușul se desfășoară însă prin kenoză, adică printr-o deșertare de

${ }^{5}$ Harry Boosalis, Viața duhovnicească Ortodoxă după Sfântul Siluan Athonitul, Cluj-

Napoca, Edit. Renaşterea, 2014, p. 161.

${ }^{6}$ Ibidem, p. 228-229. 
sine. Deșertarea de sine reprezintă de fapt coborârea omului în iad spre a trăi alături de Mântuitorul propria Înviere.

Urcușul se realizează așadar printr-o coborâre a noastră în iadul patimilor noastre. Pogorârea la iad a lui Hristos reprezintă de fapt anunțarea Învierii. Așa și deșertarea de sine a omului anunță învierea sa. Adâncul smereniei hristice este reprezentată tocmai de pogorârea la iad. Urcarea prin coborâre reprezintă de fapt un mod de viață isihast prin coborârea minții în inimă. $\mathrm{Cu}$ alte cuvinte prin rugăciune neîncetată a inimii omul începe să conștientizeze neputința sa și se lasă tot mai mult în voia lui Dumnezeu. Acesta reprezintă de fapt drumul omului de la chip la asemănare sau nașterea sa ca persoană.

Descoperirea dată Sfântului Siluan îl păzește pe om de cea mai grea patimă de mândrie. Ființa umană poate să pătrundă în iadul existenței sale și să învie cu Hristos, doar prin harul Sf. Duh. În teologia marelui nevoitor rus este imposibilă actualizarea principiului ipostatic în om fără har. $\mathrm{Cu}$ ajutorul harului ființa umană învață iubirea, rugăciunea: „Harul lui Dumnezeu dă putere de a iubi pe Cel iubit și sufletul e neîncetat atras spre rugăciune și nu poate uita pe Domnul nici măcar pentru o secundă"7.

Harul Sf. Duh pleacă din suflet pentru gândurile pătimașe. În acest moment sufletul care a cunoscut pe Hristos se tânguie pentru pierderea harului cum se tânguia Adam după pierderea raiului ${ }^{8}$. Doar prin Duhul putem cunoaște pe Hristos, iar cunoașterea lui Hristos, după cum afirmă Ysabel de Andia este sinonmă cu a cunoaște smerenia lui Hristos. „A cunoaște pe Hristos, înseamnă a cunoaște smerenia lui Hristos"”.

Darul smereniei este cel mai înalt dar al Duhului Sfânt, putem spune că smerenia este suma tuturor darurilor Sf. Duh: „Darul sfintei smerenii pe care sufletul îl cere de la Domnul este cel mai înalt dar al Duhului, care cuprinde în el pe toate celelalte"10.

În teologia marelui nevoitor rus găsim mai multe trepte ale smereniei. O treaptă a smereniei reprezintă osândirea de sine, dar cu totul alta este smerenia hristică spre care trebuie să tindem toți. În ceea ce

${ }^{7}$ Siluan AtHONITUL, Între iadul deznădejdii și iadul smereniei, Sibiu, Edit. Deisis, 2001, p. 55.

${ }^{8}$ Ibidem, p. 61.

9 Ysabel de ANDIA, „Smerenia la Sf. Siluan”, în Fratele nostru este viața noastră. Spiritualitatea Cuviosului Siluan Athonitul, Cluj-Napoca, Edit. Renaşterea, 2016, p. 82. ${ }^{10}$ Ibidem, p. 87. 
privește smerenia lui Hristos, ea are la rândul ei mai multe trepte. Începutul ei constă în acceptarea cu bucurie a necazurilor și reproșurilor:

„Cine a dobândit smerenia lui Hristos dorește totdeauana să i se facă reproșuri, primește cu bucurie necazurie și se întristează când este lăudat. Dar aceasta nu este decât primul început al smereniei. Când sufletul cunoaște prin Duhul Sfânt cât de bland și smerit e Domnul, atunci se vede pe sine însuși mai rău decât toți păcătoșii și se bucură să stea pe gunoaie în zdrențe ca Iov și să vadă pe oameni în Duhul Sfânt strălucitori și asemenea lui Hristos""11.

Dacă am vrea să definim într-un mod experiențial ce anume înseamnă smerenia lui Hristos, putem spune că ea are două aspecte care se întrepătrund. Primul constă în bucuria de a primi necazurile, a te vedea pe tine însuși mai rău decât toți, și nu în ultimul rând în a te bucura și a-i vedea pe toți în slavă asemenea Mântuitorului:

„Când pacea lui Hristos vine în suflet, atunci ele este bucuros să șadă ca Iov pe gunoi și să-i vadă pe ceilalți în slavă, atunci sufletul este bucuros că este mai rău decât toți. Taina acestei smerenii a lui Hristos e mare şi cu neputință de dezvăluit. Din iubire sufletul dorește fiecărui om mai mult bine decât pentru sine însuși și se bucură când vede că alții stau mai bine decât el și se întristează când îi vede că sunt chinuiți”"12.

\section{Rugăciunea pentru vrăjmași}

Al doilea aspect constă în rugăciunea ipostatică sau pentru întreg Adamul. Această rugăciune este asemănătoare celei rostite de Domnul Iisus în grădina Ghetsimani, rugăciune ce cuprinde nu numai pe cei ce sunt încă în această viață, ci și pe cei adormiți, și nu în ultimul rând pe cei ce se vor naște. Icoana rugăciunii ipostatice este foarte bine corelată de arh. Zaharia Zaharou cu imaginea piramidei răsturnate. Hristos nu este vârful piramidei ci baza ei. El poartă neputinţele și poverile tuturor. Asemenea și cei ce se apropie de tărâmul vieții veşnice sunt chemați să devină alături de Mântuitorul susținători ai întregului $\operatorname{cosmos}{ }^{13}$.

11 Siluan Athonitul, Între iadul deznădejdii și iadul smereniei, p. 91.

12 Ibidem, p. 87.

${ }^{13}$ Zaharia ZAHAROU, Lărgiți și voi inimile voastre (2 Corinteni 6:13): Lărgirea inimii în teologia Sfântului Siluan Athonitul și a Starețului Sofronie de la Essex, Alba-Iulia, Edit. Reîntregirea, 2009, p. 99. 
Rugăciunea ipostatică cuprinde în sine și rugăciunea pentru vrăjmaşi. Este imposibilă cunoaşterea lui Dumnezeu fără rugăciunea pentru vrăjmaşi: „Dar cine nu iubește pe vrăşmaşi, acela nu poate cunoaște pe Domnul, nici dulceață Duhului Sfânt... Cine nu iubește pe vrăjmași n-are în el harul lui Dumnezeu"14.

Această poruncă derivă în primul rând din consubstanțialitatea firii umane. Prin urmare fiecare persoană este homousios cu ceilalți: „Iubirea vrăjmașilor...este de fapt participarea dinamică și existențială a firii omenești zidite la harul nezidit al lui Dumnezeu. Credinciosul este chemat să-i iubească pe toți oamenii incluzându-i și pe vrăjmași săi pentru că este homousios sau consubstanțial cu aceștia, ceea ce înseamnă că ei sunt din aceeași fire"15.

Mai mult fiecare persoană prin firea umană este consubstanțială cu Fiul lui Dumnezeu, care a luat firea noastră omenească „firea omenească comună, fiind zidită după chipul și asemănarea Sf. Treimi este consubstanțială sau homousios cu aceea a lui Adam și a fiecărui om, cuprinzându-L și pe Fiul lui Dumnezeu Întrupat"16.

Însăși definiția de creștin ne duce cu gândul la această atârnare a unuia față de alții: „A fi creștin înseamnă tocmai a conștientiza această atârnare unii de alţii, care ne leagă de ceilalţi atât în ce privește mântuirea noastră în Iisus Hristos, cât și în ce privește păcatul. Fiindcă tot ceea ce facem și reflectăm are și o rezonanță cosmic"17.

Măsura iubirii vrăjmașilor este defapt măsura participării fiecărei persoane la energiile necreate ale lui Dumnezeu: „Se poate spune că în măsura în care credinciosul se face părtaş la harul dumnezeieștii iubiri pentru vrăjmași, în aceeași măsură se face părtaș la energiile nezidite ale vieții dumnezeiești și ale dragostei lui Dumnezeu"18.

Criteriul autenticității iubirii vrăjmaşilor, îl reprezintă trezirea păcii în inima vrăjmașului. Toată această dinamică de la despătimire la îndumnezeirea omului, de la pogorârea la iad la înviere, nu se realizează separate de viața Bisericii. Rugăciunea pentru întreaga lume reprezintă calea Bisericii, care dintotdeauna s-a rugat pentru prigonitorii săi. Practic finalitatea acestei rugăciuni este echivalentă cu scopul și misiunea

${ }^{14}$ Siluan ATHONITUL, Între iadul deznădejdii și iadul smereniei, p. 59.

${ }^{15}$ Harry Boosalis, Viața duhovnicească Ortodoxă după Sfântul Siluan Athonitul, p. 175.

${ }^{16}$ Ibidem, p. 176.

17 Maxime, EgGer, Să ne rugăm 15 zile cu Sfântul Siluan Athonitul, București, Edit. Sophia, 2010, p. 52.

${ }^{18}$ Harry Boosalis, Viața duhovnicească Ortodoxă după Sfântul Siluan Athonitul, p. 177. 
Bisericii (realizarea unității multiipostatice). În dorința de mântuire a tuturor, Biserica cuprinde chiar și pe vrăjmaşii săi. Este grăitor în acest sens un exemplu din viața starețului. Într-o discuție avută cu un călugăr athonit, care-și exprima bucuria că prigonitorii creștinismului vor merge în iad, Sf. Siluan îl întreabă dacă ar fi fericit în rai, văzându-i pe aceștia chinuindu-se în iad.

Rugăciunea pentru întreg Adamul (care cuprinde chiar și pe prigonitorii Bisericii) aduce în prim plan problema apocatastazei. În scrierile sale, Sf. Siluan respinde ideea unei mântuiri universale a desfintării iadului. Rugăciunea pentru întreaga lume nu înseamnă mântuirea tuturor. Odată cu dobândirea prin harul Sf. Duh a acestui dar, vine și întristarea că nu toți se mântuiesc Fiul lui Dumnezeu, dă monahului dragostea Sf. Duh, și din această dragoste inima monahului necontenit se întristează pentru norod că nu toți se mântuiesc"19.

Rugându-se pentru întreaga creație, nevoitorul conștientizează că Dumnezeu dorește cu ardoare mântuirea omului. Dacă Dumnezeu dorește izbăvirea tuturor rezultă că iadul nu este expresia satisfacerii unei justiţii divine, ci este rezultatul alegerii omului care refuză pe Dumnezeu și Împărătia Sa. De altminteri, nici iadul nu este lipsit de dragostea lui Dumnezeu, Care este prezent și aici. Făcându-se asemănători cu Dumnezeu și în rai petrecând ,văd iadul, și îl îmbrățișează și pe acela în dragostea lor" ${ }^{20}$. Suferința celor din iad este cauzată de neputința lor de a răspunde acestei iubiri, căreia i s-au opus în timpul vieții. Astfel iadul va însemna în primul rând neputinţa de a mai iubi.

Citind cu atenție rugăciunile Sf. Liturghii, putem observa că realizarea unității multispostatice, a rugăciunii pentru întreg Adamul se realizează numai prin taina Sf. Euharistii, unde fiecare persoană este unită cu Hristos și cu fiecare persoană umană în parte:

„Iar pe noi pe toți, care ne împărtăşim dintr-o pâine și dintr-un potir să ne unești unul cu altul prin împărtăşirea Aceluiași Sfânt Duh și pe nici unul dintre noi să nu ne faci a ne împărtăşi cu Sfântul Trup şi Sânge al Hristosului Tău spre judecată sau spre osândă, ci să aflăm şi har împreună cu toți sfinții care din veac au bineplăcut Ție: cu strămoșii, părinții, patriarhii, prorocii, apostolii, propovăduitorii, evangheliştii, mucenicii,

${ }^{19}$ Sofronie Saharov, Cuviosul Siluan Athonitul, Suceava, Edit. Accent Print, 2013, p. 236.

${ }^{20}$ Ibidem, p. 123-124. 
mărturisitorii, dascălii și cu tot sufletul cel drept care s-a săvârşit întru credinţă’"21.

\section{Concluzii}

În finalul celor expuse putem spune că în centrul spiritualității Sf. Siluan se află răspunsul la două mari întrebări: Cum se dobândește harul și cum reușim să păstrăm harul? La aceste două întrebări, starețul primește următorul răspuns de la Dumnezeu Ține-ți mintea în iad și nu deznădăjdui. Acest gând de foc este tratamentul împotriva patimii mândriei. Dacă la începutul nevoinței, ființa umană se luptă cu patimile grosolane, ultima bătălie și cea mai grea este cu mândria. Ținându-și de fiecare dată mintea în iad numai cu o mișcare a gândului, Sf. Siluan biruia orice gând al înălțării de sine. Rodul coborârii minții în iad cu nădejdea în Dumnezeu este dobândirea smereniei lui Hristos. Când nevoitorul ajunge să dobândească smerenia lui Hristos, rugăciunea sa devine una ipostatică cuprinzând întreaga creație chiar și iadul. În acest moment, omul devine cu adevărat plinitor al poruncilor, cunoscându-l pe Dumnezeu precum este.

\section{Referinţe bibliografice:}

1. Athonitul, Siluan, Intre iadul deznădejdii și iadul smereniei, Sibiu, Edit. Deisis, 2001;

2. Boosalis, Harry, Viaţa duhovnicească Ortodoxă după Sfântul Siluan Athonitul, Cluj-Napoca, Edit. Renașterea, 2014;

3. Dumnezeiasca Liturghie a Sfântului Vasile cel Mare, Bucureşti, EIBMBOR, 2012;

4. EgGER, Maxime, Să ne rugăm 15 zile cu Sfântul Siluan Athonitul, Bucureşti, Edit. Sophia, 2010;

5. Fratele nostru este viața noastră. Spiritualitatea Cuviosului Siluan Athonitul, Cluj-Napoca, Edit. Renașterea, 2016;

6. SAharov, Sofronie, Cuviosul Siluan Athonitul, Suceava, Edit. Accent Print, 2013;

7. SAHARov, Sofronie, Vom vedea pe Dumnezeu precum este, Suceava, Edit. Accent Print, 2015;

${ }^{21}$ Dumnezeiasca Liturghie a Sfântului Vasile cel Mare, Bucureşti, EIBMBOR, 2012, p. 124-125. 
8. Viața și învățătura starețului Siluan Athonitul scrise de ucenicul său arhimandritul Sofronie, Sibiu, Edit. Deisis, 2004;

9. ZaHAROU, Zaharia, Lărgiți și voi inimile voastre (2 Corinteni 6:13): Lărgirea inimii în teologia Sfântului Siluan Athonitul și a Starețului Sofronie de la Essex, Alba Iulia, Edit. Reîntregirea, 2009. 